\title{
Genetic Diversity of Local Endemic Teucrium leucophyllum Montbret \& Aucher ex Bentham. (Lamiaceae) in Turkey
}

\author{
Emel Sözen ${ }^{\text {* }}$, Muhip Hilooğlu', Ali Kandemir ${ }^{2}$ \\ ${ }^{1}$ Department of Biology, Faculty of Science, Anadolu University, 26470, Eskisehir, TURKEY \\ ${ }^{2}$ Department of Biology, Faculty of Science and Art, Erzincan University, 2400, Erzincan, TURKEY
}

\begin{abstract}
Background and Objective: Teucrium leucophyllum is endemic plant species having considerable narrow distribution in Erzincan (Turkey) Region. The aim of this study was to determine genetic diversity levels of $T$. leucophyllum in order to obtain data for its conservation. Method: Genomic DNA was isolated from 81 plants using CTAB method. Genetic diversity in four natural populations of $T$. leucophyllum was investigated by ISSR markers. A binary matrix was produced by scoring each amplified fragment as present (1) or absent (0) from each individual. The matrix was used to produce an input file and analyzed using the software programs; POPGENE 1.32 and GenAlex. Results: Twenty primers amplified a total of 434 bright and discernible bands of 220-3000 bp, of which 431 bands (PPB: 99.31\%) were polymorphic in 4 populations. The genetic diversity was high at the species level; the observed number of alleles $(\mathrm{Na})$ was 1.993 , the effective number of alleles $(\mathrm{Ne})$ was 1.404, the Nei's genetic diversity $(H)$ was 0.263 , and the Shannon's information index (/) was 0.418. A high level of gene flow (Nm: 2.208) and low-moderate genetic differentiation (Gst: 0.184) were also observed. Analysis of molecular variance showed that $11 \%$ of the total genetic diversity resided among populations, while $89 \%$ within the populations. Conclusion: Our results indicated that the conservation efforts should aim to preserve the extant populations of this endangered species in its natural habitat. Seeds could be collected from Kayacik and Bagistas populations for ex situ conservation practices.
\end{abstract}

Keywords: Genetic diversity, ISSR, PCR, Teucrium leucopyllum, Endemic plant.

\section{INTRODUCTION}

Medicinally, Teucrium (Lamiaceae) species have a long history of use as diuretic, diaphoretic, tonic, antipyretic, antidiabetic, antispasmodic, and cholagogic purposes. In Turkey, 48 Teucrium species occur naturally, of which 18 are endemic. ${ }^{1}$ Teucrium leucophyllum Montbret $\&$ Aucher ex Bentham is a rare and endemic plant species that shows narrow distribution around Erzincan (Turkey) province. According to the IUCN criteria, this species was evaluated as EX (Extinct), however, it has been rediscovered from its original localities., ${ }^{2,3}$ At present, only four populations exist in Erzincan. Besides its narrow distribution its populations are under various risks due to intensive human activities such as mining, grazing and road construction.

Estimation of genetic variation levels in endemic species is crucial to develop reliable conservation strategies. Inter simple sequence repeats (ISSRs) have been widely used for estimating genetic variation at interspecific and intraspecific levels. ${ }^{4}$ To date, various studies concerning morphological features and germination characteristics of T. leucophyllum were undertaken but no molecular study was conducted. ${ }^{3,5}$ Therefore, the aim of this study was to determine genetic diversity levels within and among the four populations of $T$. leucophyllum. The results could
DOI: 10.5530/ijper.51.3s.11 Correspondence: Emel Sözen, Department of Biology, Faculty of Science, Anadolu University, 26470, Eskisehir, TURKEY

Phone no: +90 (222) 3350580

E-mail: esozen@anadolu. edu.tr 
provide valuable information to establish effective conservation strategies for this rare and endemic plant.

\section{MATERIALS AND METHODS}

\section{Plant materials and DNA extraction}

Plant samples were collected from each populations of T. leucophyllum between June and July 2014 (Table 1). A total of 81 plants were sampled for DNA extraction. The identification of species was performed based on the Flora of Turkey and East Aegean Islands. ${ }^{6}$ The cetyl trimethyl ammonium bromide (CTAB) method was employed to isolate total genomic DNA from silica dried leaf samples. ${ }^{7}$

\section{ISSR-PCR and Data analysis}

PCR amplifications were performed in a $25 \mu \mathrm{L}$ reaction mixture using gradient thermocycler (Applied Biosystems, CA, USA). After screening 45 ISSR primers, 20 of them that amplified clear and reproducible fragments were selected for further analysis $\left[\mathrm{GAG}(\mathrm{CAA})_{5}\right.$, VHV $(\mathrm{GT})_{7} \mathrm{G},(\mathrm{GA})_{8} \mathrm{YC},(\mathrm{GA})_{8} \mathrm{~T},(\mathrm{AG})_{8} \mathrm{~T},(\mathrm{AC})_{8} \mathrm{C},(\mathrm{AGC})_{6} \mathrm{G}$, $\mathrm{DBD}(\mathrm{AC})_{7},(\mathrm{AG})_{8} \mathrm{YT},(\mathrm{TG})_{8} \mathrm{~A},(\mathrm{GACA})_{4},(\mathrm{GTTC})_{4}$, $(\mathrm{GGAT})_{4}, \quad(\mathrm{GGGTG})_{3}, \quad(\mathrm{CT})_{8} \mathrm{G}, \quad(\mathrm{TC})_{8} \mathrm{C}, \quad(\mathrm{CA})_{8} \mathrm{RC}$, $\left.(\mathrm{ACC})_{6},(\mathrm{AGC})_{6},(\mathrm{CTC})_{6}\right]$. PCR products were run on
$1.4 \%$ agarose gel containing ethidium bromide $(0.5 \mu \mathrm{g} / \mathrm{mL})$ at $90 \mathrm{~V}$ and digitally photographed.

The amplification products were scored as present (1) or absent (0) for each individual. POPGENE program v1.32) was used to calculate genetic parameters and Nei's genetic distance between individuals. ${ }^{8}$ The Analysis of Molecular Variance (AMOVA) was performed with the program GenAlEx 6.5 by resampling 999 times. ${ }^{9}$

\section{RESULTS AND DISCUSSION}

Using 20 ISSR primers, a total of 434 clear and reproducible bands was amplified, of which 431 were polymorphic. ISSR band patterns of 81 individuals from four populations using primer $(\mathrm{CTC})_{6}$ was shown in Fig. 1. The percentage of polymorphic bands $(P P B)$ ranged from $40.55 \%$ (Pop 4) to $94.47 \%$ (Pop 3) with an average of $79.14 \%$ at the population level and $99.31 \%$ at the species level (Table 2). The observed number of alleles $(\mathrm{Na})$ ranged from 1.405 to 1.944 , while the effective number of alleles $(\mathrm{Ne})$ varied from 1.263 to 1.398 . Nei's genetic diversity $(H)$ varied from 0.153 to 0.249 , with an average of 0.220 , and Shannon's information indices $(I)$ ranged from 0.228 to 0.392 , with an average of 0.345 . At species level, $\mathrm{Na}, \mathrm{Ne}, \mathrm{H}$ and $I$ were 1.993,

\section{Table 1: Sampling details of $T$. leucophyllum populations from Erzincan region}

\begin{tabular}{|c|c|c|c|c|}
\hline Population locality & Population code & Sample size & Altitude (m) & Longitude (E)/Latitude (N) \\
\hline İliç/Kayacık 1 & Pop 1 & 23 & $920-944$ & 37 S 451970 E, 4367486 N \\
\hline İliç/Kayacık 2 & Pop 2 & 22 & $950-1350$ & $37452122 \mathrm{E}, 4365875 \mathrm{~N}$ \\
\hline İliç/Bağıştaş-Salihli & Pop 3 & 33 & $952-975$ & $37454137 \mathrm{E}, 4361001 \mathrm{~N}$ \\
\hline Kemaliye/Binkoçlu & Pop 4 & 3 & 1314 & $37455721 \mathrm{E}, 4350433 \mathrm{~N}$ \\
\hline
\end{tabular}

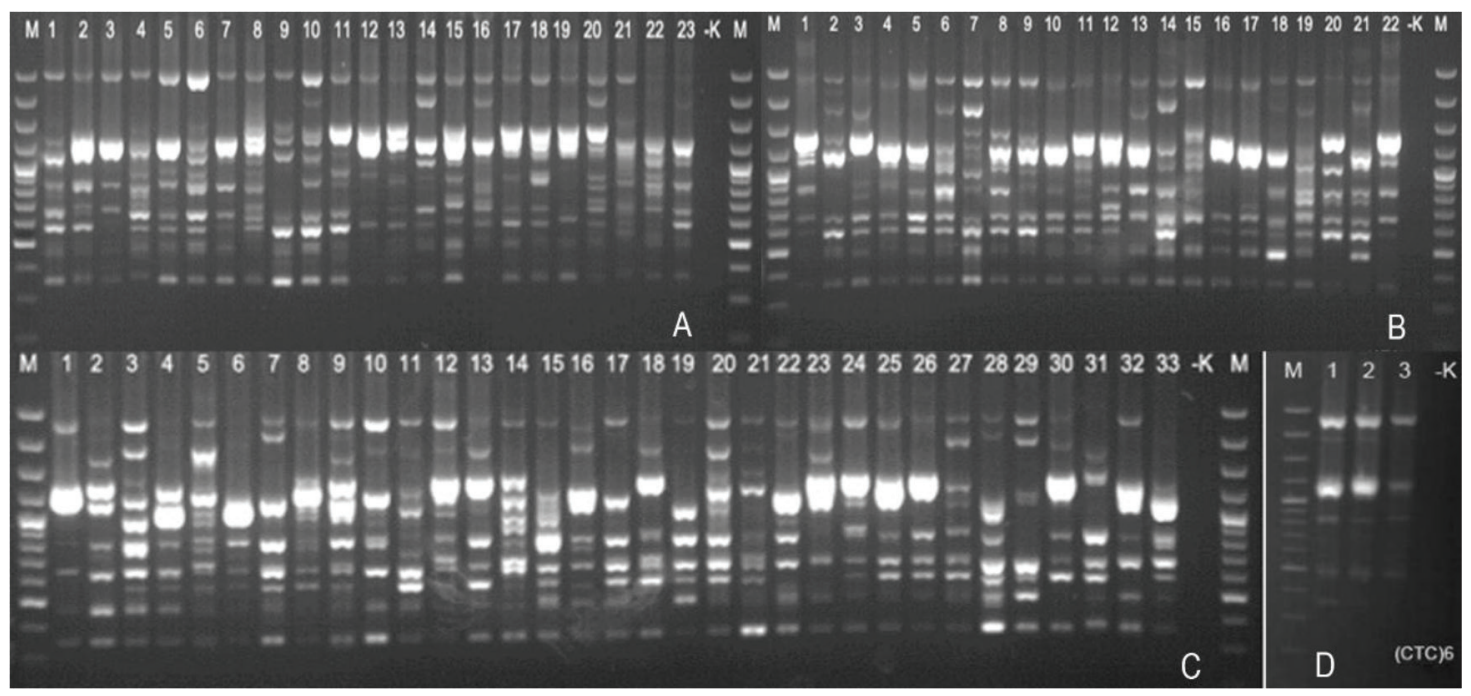

Figure 1: ISSR profiles of 81 individuals (4 populations) of T. leucophyllum using (CTC) ${ }_{6}$ primer (M: GeneRuler 100 bp Ladder Plus, -K: a negative control). 


\begin{tabular}{|c|c|c|c|c|c|}
\multicolumn{6}{|c|}{ Table 2: Genetic diversity of T. leucophyllum } \\
populations \\
\hline Population & $N a(s d)$ & $N e(s d)$ & $H(s d)$ & $I(s d)$ & $\begin{array}{c}P P B \\
(\%)\end{array}$ \\
\hline Pop 1 & $\begin{array}{c}1.900 \\
(0.299)\end{array}$ & $\begin{array}{c}1.372 \\
(0.301)\end{array}$ & $\begin{array}{c}0.237 \\
(0.157)\end{array}$ & $\begin{array}{c}0.375 \\
(0.213)\end{array}$ & 90.09 \\
\hline Pop 2 & $\begin{array}{c}1.914 \\
(0.279)\end{array}$ & $\begin{array}{c}1.398 \\
(0.313)\end{array}$ & $\begin{array}{c}0.249 \\
(0.158)\end{array}$ & $\begin{array}{c}0.392 \\
(0.212)\end{array}$ & 91.47 \\
\hline Pop 3 & $\begin{array}{c}1.944 \\
(0.228)\end{array}$ & $\begin{array}{c}1.381 \\
(0.301)\end{array}$ & $\begin{array}{c}0.243 \\
(0.153)\end{array}$ & $\begin{array}{c}0.385 \\
(0.204)\end{array}$ & 94.47 \\
\hline Pop 4 & $\begin{array}{c}1.405 \\
(0.491)\end{array}$ & $\begin{array}{c}1.263 \\
(0.359)\end{array}$ & $\begin{array}{c}0.153 \\
(0.195)\end{array}$ & $\begin{array}{c}0.228 \\
(0.284)\end{array}$ & 40.55 \\
\hline Average & $\begin{array}{c}1.791 \\
(0.018)\end{array}$ & $\begin{array}{c}1.353 \\
(0.008)\end{array}$ & $\begin{array}{c}0.220 \\
(0.004)\end{array}$ & $\begin{array}{c}0.345 \\
(0.006)\end{array}$ & 79.14 \\
\hline Species & $\begin{array}{c}1.993 \\
(0.082)\end{array}$ & $\begin{array}{c}1.404 \\
(0.267)\end{array}$ & $\begin{array}{c}0.263 \\
(0.132)\end{array}$ & $\begin{array}{c}0.418 \\
(0.171)\end{array}$ & 99.31 \\
\hline
\end{tabular}

$\mathrm{Na}$ : observed number of alleles; Ne: effective number of alleles; $\mathrm{H}$ : Nei's gene diversity; I: Shannon's information indeces; PPB: percentage of polymorphic bands; sd: standard deviation.

$1.404,0.263$ and 0.418 , respectively. The highest variability levels were observed in Pop 2 (Hs: 0.249, I: 0.392) wheras lowest levels were observed in Pop 4 (Hs: 0.153, I: 0.228).

Generally, a low level of genetic diversity is commonly expected for endemic and geographically restricted species. ${ }^{10}$ Interestingly, despite of its narrow distribution T. leucophyllum maintains high levels of genetic diversity (PPB: 99.31\%, H: 0.263, I: 0.418) compared to levels of genetic diversity found in other endemic species. Similarly, numerous findings have been reported for many narrow endemic species maintaining high genetic diversity; for example, Helenium virginicum (PPB: \% 98.5, HT: 0.324, I: 0.484), Lilium regale (PPB: $97.3 \%, H: 0.198, I: 0.333) .{ }^{11,12}$ Hamrick and Godt reported that outcrossing perennial species commonly have higher levels of genetic diversity than selfing and clonal plants. ${ }^{10}$ T. leucophyllum is perennial plant reproducing both sexually and asexually. We have observed moderate level of seed set but seed germination was very low (13.5\%) and can only be increased up to $52.5 \%$ with $\mathrm{GA}_{3}$ application under laboratory conditions. ${ }^{5}$ How many seeds germinate in its natural habitats is unknown, however, it was reported that succesfull establishment of one or a few seedlings should be enough to maintain high levels of genetic variation in plant populations. ${ }^{13}$ Several studies proposed that asexual reproduction may promote the maintainance of high genetic diversity in plants. ${ }^{14}$ Therefore, it could be speculated that T. leucophyllum reproduced sexually in its recent history and substantial amount of its genetic diversity was maintained with its clonal growth and perennial characteristics.
AMOVA analysis (89\%) and Shannon's information measure $(82.6 \%)$ demonstrated that majority of the total genetic variation partitioned within populations. Gst values between $0.05-0.15$ indicate a low level of genetic differentiation whereas $\mathrm{G} s t$ values above 0.30 indicate high level of genetic differentiation among populations. ${ }^{15}$ We have found low-moderate level of genetic differentiation among populations of $T$. leucophyllum (Gst. 0.184). This value is comparatively low from that of non-endemic Teucrium polium (Gst. 0.38). ${ }^{16}$ However, there are several studies representing high genetic diversity and low population genetic differentiation in rare and endemic plant species such as Salvia lachnostachys (Gst. 0.167) and Magnolia wufengensis (Gst. 0.171). ${ }^{17,18}$ High genetic diversity and low population differentation in endemic plants have been attributed to a number of factors e.g. inadequate time for lowering genetic diversity following isolation, reduction in population size, recent fragmentation of continuous genetic system, and substantial gene flow. ${ }^{19,20}$ In T. leucophyllum, we observed high gene flow between populations (Nm:2.208). Usually, a gene flow equal or higher than $1(N m \geq 1)$ is sufficient to prevent significant population differentiation among populations ${ }^{21}$ and this is attributed to the long-distance pollen or seed dispersal ability of plant. Most probably, seed dispersal mode and insect pollination may be contributed to the gene flow among closely located T. leucophyllum populations. In our field study, we observed that T. leucophyllum grows on crevices of limestone rocks. Habitat specificity of this species makes it vulnerable and to be affected seriously from habitat loss and enviromental change. Our previous investigation revealed that T. leucopbyllum is under threat of human interference, destruction and habitat fragmentation. Therefore, despite of its high levels of genetic diversity, narrow distribution and habitat specifity of T. leucophyllum may negatively effect maintenance of its populations in the future.

\section{CONCLUSION}

This study have shown that the endangered status of T. leucophyllum is not due to the degree of its genetic variation but its narrow distribution on specific habitat. Conservation efforts for this species should be concentrated on protecting its natural habitat first. In addition, seeds can be collected from populations located in Kayacık and Bağıştaş for ex-situ conservation practices.

\section{ACKNOWLEDGMENTS}

This research was supported by Scientific And Technological Research Council of Turkey-TUBITAK (Project No. 110T912). 


\section{CONFLICT OF INTEREST}

None

\section{ABBREVIATION USED}

CTAB: Cetyl Trimethyl Ammonium Bromide; ISSR: Inter Simple Sequence Repeat; PPB: Percentage of Polymorphic Band; IUCN: The International Union for Conservation of Nature; $\mathrm{Na}$ : the observed number of alleles; $N e$ : the effective number of alleles; $H$ : the Nei's genetic diversity; $I$ : the Shannon's information index; Nm: Number of Migrants; Gst: A measure of Genetic differentiation; EX: Extinct; DNA: Deoxyribo Nucleic Acid; AMOVA: The Analysis of Molecular Variance; GA3: Gibberellic acid; TUBITAK: The Scientific And Technological Research Council of Turkey.

\section{REFERENCES}

1. Sagirli PA, Ozsoy N, Genc GE, Melikoglu G. In vitro antioxidant activity, cyclooxygenase-2, thioredoxin reductase Inhibition and DNA protection properties of Teucrium sandrasicum L. Industrial Crops and Products. 2015;74:545-50

2. Ekim T, Koyuncu M, Vural M, Duman H, Aytaç Z, Adıgüzel N. Red data book of turkish plants (Ferns and seed plants). Publications of Association of Turkey's Nature Conservation. Ankara; 2000.

3. Kandemir A. The observations on Teucrium leucophyllum Montbret \& Aucher ex Benth. (Lamiaceae) endemic to Turkey, Erzincan Üniv Fen Bil Enst Derg. 2010(2):191-6.

4. Tabin S, Kamili AN, Ganie SA, Zargar O, Sharma V, Gupta RC. Genetic diversity and population structure of Rheum species in Kashmir Himalaya based on ISSR markers. Flora. 2016;223:121-8.

5. Hilooğlu M, Yücel E, Kandemir A, Sözen E. In vitro seed germination study in endemic plant Teucrium leucophyllum (Lamiaceae). Sinop University Journal of Natural Sciences. 2016;1:53-1.

6. Davis PH, Mill RR, Tan K. Flora of Turkey and the East Aegean Islands (Suppl. 1), Vol. 10. Edinburg, UK: Edinburgh University Press; 1988.
7. Doyle JJ, Doyle JL. A rapid DNA isolation procedure from small quantities of fresh leaf tissues. Phytochem Bull 1987;19:11-5.

8. Yeh FC, Yang RC, Boyle T. Popgene version 1.31 Microsoft Window-based Freeware for Population Genetic Analysis. Canada: University of Alberta and Center for International Forestry Research; 1999.

9. Peakall R, Smouse PE. GenAIEx 6.5: Genetic analysis in Excel. Population genetic software for teaching and research-an update. Bioinformatics. 2012;28:2537-39.

10. Hamrick JL, Godt MJW. Allozyme diversity in plants. In Brown, A.H.D, Clegg, M.T, Kahler, A.L, Weir, B.S. (Eds.), Plant Population Genetics, Breeding and Genetic Resources 123, Sinauer, Sunderland; 1989

11. Knox JS, Bezold K, Cabe PR, Simurda MC, Williams S, Simurda MC. Genetic diversity and population structure of the endemic disjunct species, Helenium virginicum (Asteraceae) Am Midl Nat. 2016;175(2):242-60.

12. Wu ZH, Shi J, Xi ML, Jiang FX, Deng MW, Dayanandan S. Inter Simple sequence repeat data reveals high genetic diversity in wild populations of the narrowly distributed endemic Lilium regale in the Minjiang River Valley of China. PloS One 2015;10: e0118831.

13. Watkinson AR, Powell JC. Seedling recruitment and the maintenance of clonal diversity in plant populations computer simulation of Ranunculus repens. J Ecol. 1993;81:707-17.

14. Mitton JB, Grant MC. Genetic variation and the natural history of quaking aspen. Bioscience. 1996;46(1):25-1.

15. Wright S. Evolution and the genetics of populations. In: Variability within and among natural populations, vol. 4. Chicago: University of Chicago Press. 1978.

16. Boulila A, Béjaoui A, Messaoud C, Boussaid M. Genetic diversity and population structure of Teucrium polium (Lamiaceae) in Tunisia. Biochemical Genetics. 2010;48(1):57-70.

17. Erbano M, Schühli GSE, Santos EP. Genetic variability and population structure of Salvia lachnostachys: Implications for breeding and conservation programs. International Journal of Molecular Sciences. 2015;16(4):7839-50.

18. Chen L, Chen F, He S, Ma L. High genetic diversity and small genetic variation among populations of Magnolia wufengensis (Magnoliaceae), revealed by ISSR and SRAP markers. Electronic Journal of Biotechnology. 2014;17(6):268-4.

19. Zawko G, Krauss SL, Dixon KW, Sivasithamparam K. Conservation genetics of the rare and endangered Leucopogon obtectus (Ericaceae). Mol Ecol. 2001;10(10):2389-96.

20. Maguire TL, Sedgley M. Genetic diversity in Banksia and Dryandra (Proteaceae) with emphasis on Banksia cuneata, a rare and endangered species. Heredity. 1997;79(4):394-1.

21. Slatkin M. Gene flow and the geographic structure of natural populations. Science. 1987;236(4803):787-2.

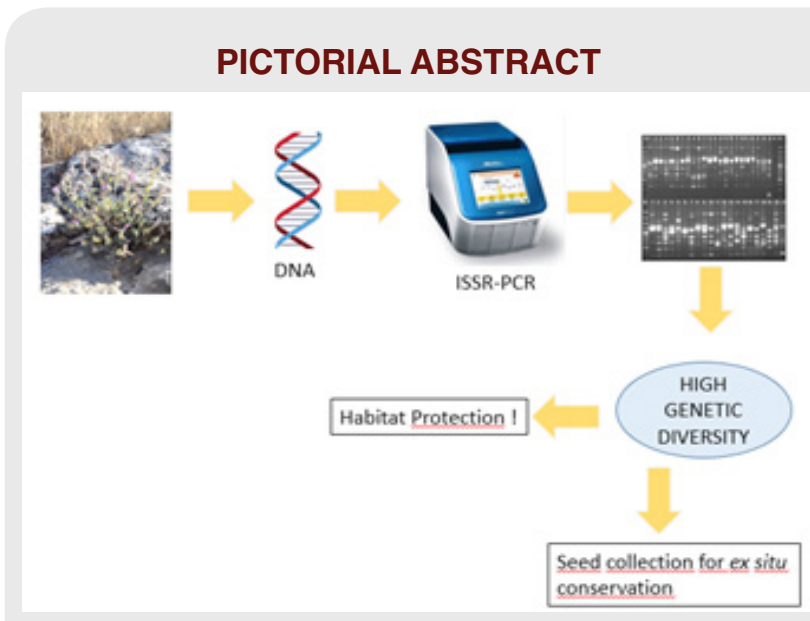

\section{SUMMARY}

- Teucrium leucophyllum is endemic plant species having considerable narrow distribution in Turkey. Beside, its populations are under various risks due to human activities.

- ISSR analyses showed that Teucrium leucophy/lum possess high level of genetic diversity.

- Therefore, the endangered status of T. leucophy/lum is not due to the degree of its genetic variation but its narrow distribution on specific habitat.

- Conservation strategies should be developed for protecting its habitats first and seeds also can be collected for ex situ conservation practices. 


\section{About Authors}

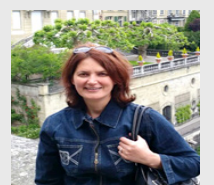

Dr. Emel Sözen is working at Department of Biology, Anadolu University, Turkey. Her research interests are in the area of plant genetics, she is particularly focused on genetic diversity of endemic plants using molecular markers.

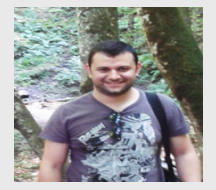

Dr. Muhip Hilooğlu has completed his Ph.D. from Department of Biology Botany Division at Anadolu University, Turkey. His area of research interest is plant genetics, population genetics, PCR based markers, genetic relationship, endemism and ecology.

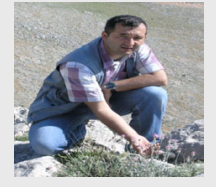

Dr. Ali Kandemir is working at Department of Biology, Art and Science Faculty of Erzincan University-Turkey. His subject is on plant taxonomy and plant conservation. He has authored and coauthored more than 50 research articles. He is one of the editors of Turkish Illustrated Flora. Dr. Kandemir also worked on Caryophyllaceae family of Iraqi Flora.

Cite this article: Sözen E, Hilooglu M, Kandemir A. Genetic Diversity of Local Endemic Teucrium leucophyllum Montbret \& Aucher ex Bentham. (Lamiaceae) in Turkey. Indian J of Pharmaceutical Education and Research. 2017;51(3)Suppl:S195-99 